\title{
Controversial Topics and Their Didactic Use: Analysis of the Activities Included in Italian and Spanish Textbooks
}

Mario Ferreras-Listán ${ }^{1}$, José Antonio Pineda-Alfonso², Coral Ivy Hunt-Gómez ${ }^{3}$, Pablo Baisotti ${ }^{4}$

1 University of Seville, Department of Experimental and Social Sciences Teaching, C/Pirotecnia, s/n, ES-41013, Seville, Spain, mferreras@us.es

2 University of Seville, Department of Experimental and Social Sciences Teaching, C/Pirotecnia, s/n, ES-41013, Seville, Spain, apineda@us.es

3 University of Seville, Department of Language and Teaching, C/Pirotecnia, s/n, ES-41013, Seville, Spain coralhuntg@us.es

4 University of Costa Rica, Department of History of Costa Rica and Latin America, C/San Pedro de Montes de Oca, San José, Costa Rica, pablo.a.baisotti@hotmail.com

Abstract. This paper explores the didactic treatment of Franco's dictatorship and Mussolini's Fascism in History textbooks at a Secondary Education level. Using a mixed methodology, 278 activities were analysed and a typology was established. Despite that, the studied literature clearly advocates for the use of controversial topics due to their high educational potential, results show that controversial topics are avoided in the analysed textbooks, as they provide teachers an „aseptic recipe“ to deal with them.

Keywords: textbook, citizenship education, history and culture teaching, secondary education.

\section{History, Citizenship and Controversial Topics}

A panoramic revision of the ERIC database from the last five years provides 293 studies on Social Sciences textbooks ${ }^{1}$. Books were edited between 2005 and 2015. Only 5 of them refer to didactic aspects. To cover this gap, the present study explores the didactic

1 The Institute of Education Sciences database (ERIC database) is a high impact international database that is generally used for bibliographical and systematic literature revisions in the field of education. 
scope and treatment that a specific historical time is given. The time studied is Franco's dictatorship in Spain (1939-1975) and fascism in Italy (1922-1945). Both periods of time are potentially controversial, not only from a historiographical perspective but also regarding the pedagogical treatment received (Díez Gutiérrez, 2011). As will be examined at the methodology section, the studied periods allow to generate argumentative and discussion processes. In this way, syllabus becomes more flexible and allows the inclusion of problems, hypothesis and information gathering that will help students generating conclusions.

In the following paragraphs, we will examine several studies explore the way textbooks act as the main tool to foster the traditional transmission didactic model, based on the teacher's explanation, as well as in the performance of mechanical tasks and students' memorization. Contrary to that, there are many examples in scientific international literature that corroborate that dealing with controversial topics in the classroom develops many skills and competences of great educational value.

From this perspective, it's obvious that historical training in compulsory education levels should foster the development of student's abilities to be familiarized with and being able to manage information sources linked to History building. Therefore, teaching this subject exclusively using a traditional textbook transmission-based approach seems not to be an adequate manner if we aim to educate critical citizens (Gómez, Cózar, \& Miralles, 2014).

Students should be initiated in the understanding of History as an interpretative science, as are the rest of Social Sciences. A science that intends to rebuild and interpret the humans' past constitutes an excellent way to help students develop critical thinking, which is essential to succeed in participative and open societies. This matter is especially relevant in the case of History, because, from its very origins, it has been used to model (or, at least, try to model) subjects and citizens according to the interests of a particular time (Rodríguez-Pérez, Simón-García, \& Molina-Puche, 2017).

A way to connect History teaching and students' interest can be the use of current controversial topics (Hicks, Holden, 2007; Hand, \& Levinson, 2012; Jerome, \& Elwick, 2020) Research shows that controversial topics, approached through controversial questions, increase students' interest and involvement, help them to better acquire and comprehend knowledge, and foster their intellectual independence (Stradlong, Noctor, \& Baines, 1984).

In this line, there are many studies that advocate for the incorporation of controversial questions to the educative syllabus (Wellington, 1986). Some researchers have even stated that any school or educational institution that intentionally avoids the use of controversial questions should be accused of negligence or malpractice (Stradling, Noctor, \& Baines, 1984; Oulton, Dillon, \& Marcus, 2004).

One of the underlying problems associated with controversial topics treatment is the role of discrepancy in debates, that is, conflict management when debating. Research 
suggests that teachers' training for these kinds of activities is especially difficult in contexts with deep social divisions (Parker \& Hess, 2001; Schuitema, Radstake, Van de Pol, \& Veugelers, 2018; Aivelo, \& Uitto, 2019). In the Anglo-Saxon moral education sphere, the terms 'loyal disagreement' or 'reasonable heresy' were included as an attempt to overcome the binary concepts of loyalty and rebellion (McDonough, 2010). From those worried about the maintenance of the social order perspective, disagreement is interpreted as something destructive. However, for those that are worried about educating for democratic citizenship, and, particularly, worried about the introduction of democracy in education, the concept of 'loyal disagreement' is paramount.

Besides, many authors state that, if according to legal norms and it is clear educational value, the analysis of current social problems in the classroom is recommended, why are there reservations to normalise them in the educational syllabus? One possible explanation is that the nature of polemic makes teachers feel insecure and uncomfortable in their classrooms when working with socially conflictive problems. In this line of thinking, many studies reflect that teachers are well aware of the impact their opinions have on students, and that puts them at risk of indoctrination (Cotton, 2006). It should be noted that, even if the intellectual conflict could lead to potentially constructive results, it also could lead to potentially destructive ones (Johnson, \& Johnson, 2009).

One possible way of resolving this dilemma is the use of textbooks, because it keeps teachers apart from the conflicts caused by entering into controversial matters in the classroom. There is a strong consensus among researchers regarding how teaching exclusively following the coursebook implies static and invariable contents that are questioned neither by the teachers nor by the students (Martínez Bonafé, 2008). Thus, in practice, many textbooks represent the professional habitus, specifically at the Secondary Education level (Martínez, Valls, \& Pineda, 2009). For History textbooks, several studies conclude that it continues to be the nearly unique resource used in some educational levels (Martínez, Valls, \& Pineda, 2009).

Some specialists associate this majoritarian use of the History textbook with the prevalence of a specific didactic model and a traditional discourse, informative and encyclopaedic. This implies a proposal for repetitive and superficial activities based on memorisation and reproduction, without any other problem-based approach to historical phenomena, Therefore, they do not contribute to the development of basic educational aims (Sáiz, 2013). In this way, the contents and activities suggested are not fostering students' argumentation and reflexive skills, which are competences, linked to historical thinking, and that are included in the educational aims of the teaching of History in Secondary Education (Valls, 2008). 


\section{Methodology}

The methodology can be catalogued as a "mixed method" (Cohen, Manion, \& Morrison, 2013). An interpretative discourse analysis is performed, however, instruments from a rationalist paradigm are also used -such as the establishment of a category system or the quantitative analysis when considered useful for the research-. Research problems concern the way controversial topics are pedagogically dealt with in the analysed textbooks.

1. How are potentially controversial topics dealt with from a pedagogical perspective in the analysed textbooks?

2. What types of activities are suggested and how is the didactic sequence defined?

3. What types of contents are suggested to work with in these activities?

4. Is the same didactic treatment applied in medium and higher educational levels?

5. Are there any differences in the didactic treatment in the Italian and Spanish textbooks?

After revising several History textbooks from different publishing houses for the levels of Secondary Education and Baccalaureate, it was concluded that Fascism and the Franco regime were mainly included in the $4^{\text {th }}$ year of Secondary Education and the $2^{\text {nd }}$ year of Baccalaureate in Spain. In the case of Italy, these contents were included in the $1^{\text {st }}$ and $2^{\text {nd }}$ years of Secondary Education.

Once the years in which the specified content was usually worked were located, a sample was built composed of two textbooks per academic year were selected. There were a total of eight textbooks, four Spanish (two for the Secondary Education stage and two for Baccalaureate) and four Italian textbooks (two for the $1^{\text {st }}$ year of Secondary Education and two for the $2^{\text {nd }}$ ). The publishing houses chosen were those that had great diffusion and those were frequently used in each country. They were Pearson, DeAgostini, Mondadori, and Rizzoli for the Italian textbooks; and Oxford, Anaya, Algaida, and Santillana for the Spanish textbooks (Table 1). 
Table 1

Research Sample

\begin{tabular}{|c|c|c|c|c|}
\hline & $\begin{array}{c}\text { Textbook title /authors / publishing house / } \\
\text { year }\end{array}$ & $\begin{array}{l}\text { Year (Secondary } \\
\text { Education or post com- } \\
\text { pulsory education) }\end{array}$ & $\begin{array}{l}\text { Age of the } \\
\text { student }\end{array}$ & Code \\
\hline \multirow{4}{*}{ 突 } & $\begin{array}{l}\text { Epoche. Alberto De Bernardi y Scipione } \\
\text { Guarracino. PEARSON. } 2012\end{array}$ & $\begin{array}{l}3^{\text {rd }} \text { year Secondary } \\
\text { Education First Degree }\end{array}$ & $13-14$ & IM1 \\
\hline & $\begin{array}{l}\text { Scoprire la Storia. L'Età contempora- } \\
\text { nea. Gianfranco Bresich y Cinzia Fiorio. } \\
\text { DEAGOSTINI. } 2010\end{array}$ & $\begin{array}{l}3^{\text {rd }} \text { year Secondary } \\
\text { Education First Degree }\end{array}$ & $13-14$ & IM2 \\
\hline & $\begin{array}{l}\text { Parlate di Storia 3. Il Novecento e il } \\
\text { Mondo. Contemporáneo Marco Fossati, } \\
\text { Giorgio Luppi y Emilio Zanette, PEARSON } \\
\text { MONDADORI. } 2009\end{array}$ & $\begin{array}{l}3^{\text {rd }} \text { year Secondary } \\
\text { Education Second } \\
\text { Degree }\end{array}$ & $16-17$ & IS1 \\
\hline & $\begin{array}{l}\text { Nel segno dei tempi. Il Novecento e il } \\
\text { Duemila, La Nuova Italia. Valerio Cas- } \\
\text { tronovo. RIZZOLI. } 2015\end{array}$ & $\begin{array}{l}3^{\text {rd }} \text { year Secondary } \\
\text { Education Second } \\
\text { Degree }\end{array}$ & $16-17$ & IS2 \\
\hline \multirow{4}{*}{ Z } & $\begin{array}{l}\text { Historia. Proyecto Ánfora (edición } \\
\text { Andalucía). } \\
\text { Manuel Díaz Rubianos y otros. OXFORD. } \\
2008\end{array}$ & $\begin{array}{l}4^{\text {th }} \text { year Secondary } \\
\text { Education }\end{array}$ & $15-16$ & EM1 \\
\hline & $\begin{array}{l}\text { Historia. Ciencias Sociales. M. Burgos y } \\
\text { M.C Muñoz Delgado. ANAYA. } 2008\end{array}$ & $\begin{array}{l}4^{\text {th }} \text { year Secondary } \\
\text { Education }\end{array}$ & $15-16$ & EM2 \\
\hline & $\begin{array}{l}\text { Historia de España. Manuel Burgos (Co- } \\
\text { ord.). ALGAIDA. } 2012\end{array}$ & $2^{\text {nd }}$ year Baccalaureate & $17-18$ & ES1 \\
\hline & $\begin{array}{l}\text { Historia de España, } 2^{\circ} \text { de Bachillerato. } \\
\text { J. Manuel Fernández Ros y otros. SANTIL- } \\
\text { LANA. } 2015\end{array}$ & $2^{\text {nd }}$ year Baccalaureate & $17-18$ & ES2 \\
\hline
\end{tabular}

Taking into consideration the previous research that has been analysed in the theoretical framework, a category system was established (Table 2). That system deals with the "Didactic Consideration of the Activities" according to the aims of the study. The system was created using a revision and adaptation of different clarifications and protocols covered by Travé, Pozuelos, Cañal, \& De las Heras (2013).

There were three different categories: 'Types of contents' (which are suggested in the activities), 'Didactic sequence' (the order in which the activities are placed) and, 'Types of activities' (according to their characteristics and didactic function). Each category has been defined using indicators and descriptors that have allowed a degree of systematisation and the codification of the discursive fragments used in textbooks. A total of 278 activities that were included in the 8 textbooks conforming to the sample were analysed. 


\begin{tabular}{|c|c|c|c|}
\hline & Category & Indicators & Descriptors \\
\hline \multirow{12}{*}{ 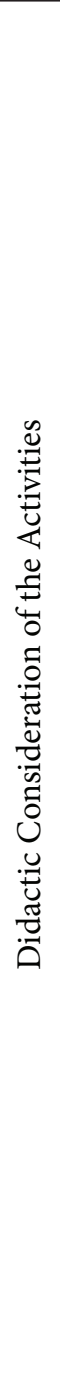 } & \multirow{4}{*}{$\begin{array}{l}\text { 1. Types of } \\
\text { contents }\end{array}$} & Factual & $\begin{array}{l}\text { To complete the activity it is necessary to master data or } \\
\text { factual information, dates, figures, name of characters or } \\
\text { institutions, etc. }\end{array}$ \\
\hline & & Conceptual & $\begin{array}{l}\text { To complete the activity it is necessary to master specific or } \\
\text { general concepts of Social Sciences. }\end{array}$ \\
\hline & & Procedural & $\begin{array}{l}\text { To complete the activity it is necessary to perform a re- } \\
\text { search, information treatment, and communication process } \\
\text { personally made. }\end{array}$ \\
\hline & & Attitudinal & $\begin{array}{l}\text { To complete the activity it is necessary to acquire a posi- } \\
\text { tioning or to issue an axiological value, linked to principles } \\
\text { and norms. }\end{array}$ \\
\hline & \multirow{3}{*}{$\begin{array}{l}\text { 2. Didactic } \\
\text { sequence }\end{array}$} & Introductory & Introductory activities at the beginning of the unit. \\
\hline & & Development & Activities to develop the topic. \\
\hline & & Closing & Activities that appear at the end of the unit. \\
\hline & \multirow{5}{*}{$\begin{array}{l}\text { 3. Types of } \\
\text { activities }\end{array}$} & $\begin{array}{l}\text { Mechanical } \\
\text { exercises }\end{array}$ & $\begin{array}{l}\text { Repetitive activities that do not require the comprehension } \\
\text { of contents, generally the correct answer lies within the } \\
\text { enclosed text. }\end{array}$ \\
\hline & & $\begin{array}{l}\text { Comprehensive } \\
\text { activities }\end{array}$ & $\begin{array}{l}\text { Activities that need a certain degree of elaboration and a } \\
\text { complex intellectual. }\end{array}$ \\
\hline & & $\begin{array}{l}\text { Quasi-investi- } \\
\text { gative activities }\end{array}$ & $\begin{array}{l}\text { Activities that imply some tasks linked to school research, } \\
\text { even if the complete process is not followed. It assimilates } \\
\text { research to information gathering. }\end{array}$ \\
\hline & & $\begin{array}{l}\text { Participatory } \\
\text { activities }\end{array}$ & $\begin{array}{l}\text { Activities that imply, not only, intellectual exercise but also } \\
\text { some active conducts and decision-making (role-playing, } \\
\text { teamwork, debates, etc.). }\end{array}$ \\
\hline & & $\begin{array}{l}\text { Research-based } \\
\text { activities }\end{array}$ & $\begin{array}{l}\text { Activities aimed at the development of complex intellec- } \\
\text { tual activities, such as, elaborating hypothesis, looking for } \\
\text { causal relations, and contrasting pieces of information or } \\
\text { extracting conclusions among others. }\end{array}$ \\
\hline
\end{tabular}

The established categories system is as descriptive as possible and far from any interpretative bias. Therefore, indicators and descriptors are not a priori strictly organised according to the hypothesis of a progression. Nonetheless, they are expected to provide valuable information intended to establish a textbook typology. This order is expected to follow a grading system that goes from a less complex close to the traditional transmissive didactic model to a more complex one, coherent with the prescribed educational aims of the History teaching and learning process. 


\section{Data analysis}

\section{Quantitative analysis}

According to the established category system, some series of figures with perceptual data of the three aspects analysed are explained.

In the section devoted to the type of contents, the most frequent are the conceptual ones followed by the factual contents, both of them with results on between $70 \%$ and $95 \%$ in all the analysed books. The minimal presence of procedural contents has to be highlighted as well as the nearly complete lack of attitudinal ones (Figure 1).

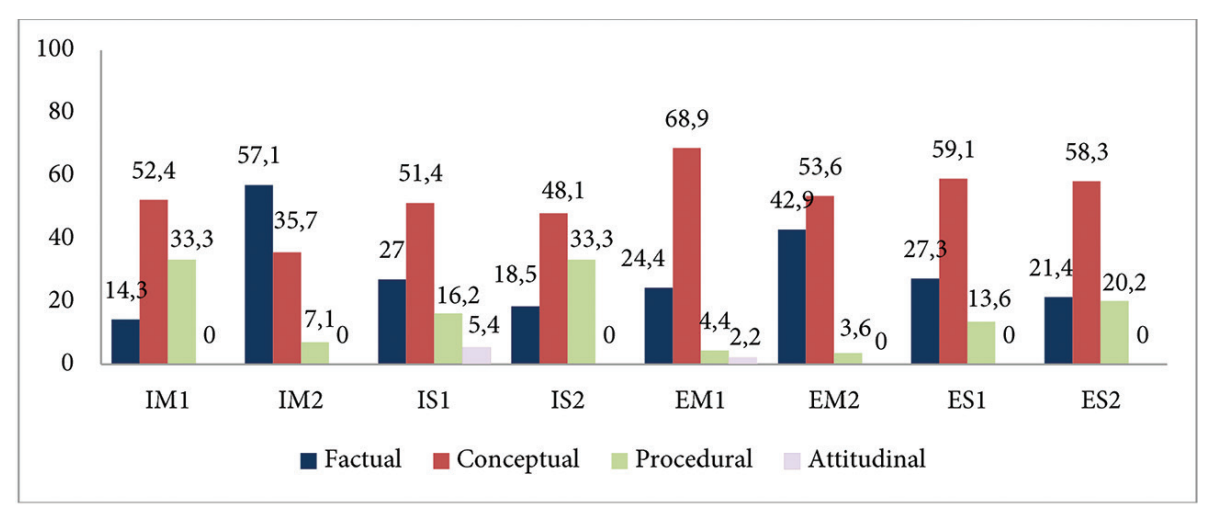

Figure 1. Percentage Values of the Types of Contents Analysed

The analysis reveals that, in textbooks from both countries, factual contents present a higher presence in medium educational levels. On the contrary, procedural and attitudinal contents are more frequent at higher levels. Conceptual contents present similar percentages in medium and higher levels.

Regarding the materialisation of didactic sequences, it seems that introductory activities are not always present. In fact, there were only three introductory activities in three of the four Spanish books analysed and none at all in the Italian ones. Besides, when comparing them to the rest of the activities, they present the lower representation, and if they are represented, and they show the lowest percentage (Figure 2). 


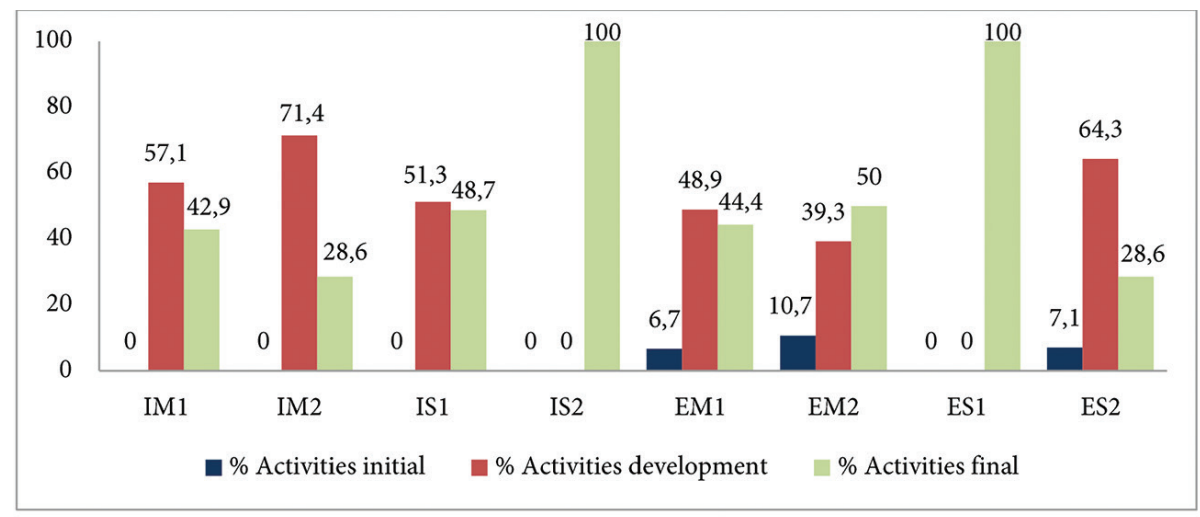

Figure 2. Percentage Values of the Activities Included in the Didactic Sequences

The analysis performed corroborated a higher number of mechanical activities in the textbooks of both countries. In medium levels as well as higher levels, this was more significant in the case of Spanish textbooks (Figure 3). Besides, in both countries, the percentage of mechanical activities in medium levels is higher than in the most advanced ones. Comprehensive activities present a higher percentage in more advanced levels. As quasi-investigative, participative and research-based activities are closer to a didactic model that aims for school-research, they have been grouped in one item. The case of Italian textbooks should be highlighted, as these types of activities are only present in higher educational levels. In Spanish textbooks, the proportion seems to be more balanced.

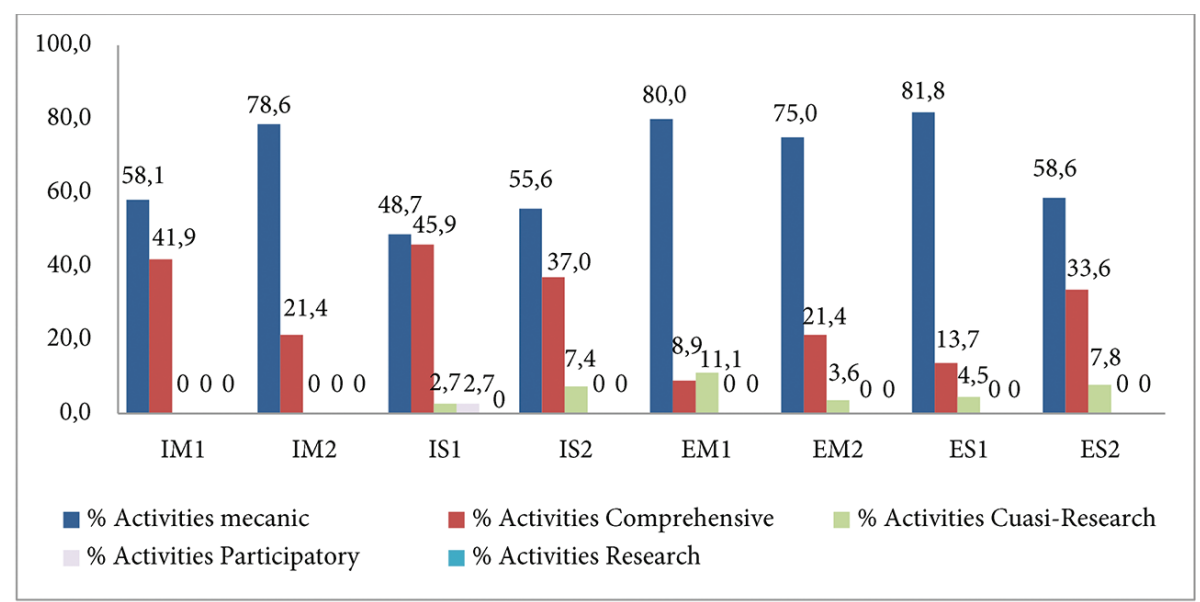

Figure 3. Percentage of the Types of Activities 


\section{Qualitative analysis}

\section{First category: 'Types of content'}

Some factual content activities, in which students need to manage historical data, using a chronological axis or a closed question, have been detected. In the book with code IS1, section 'Punti Fermi', page 116, a date is the expected answer to the question: When does fascism appear? Other activities suggest making lists, synoptic schemes, or tables placing different factual contents, names of historical characters, institutions, dates, etc. An example of this can be found in the textbook with code ES1, page 321, in which students have to establish links between the elements provided, which were only facts -INI, Hendaya, Infante Juan of Spain, 1947, among others.

Also, activities to work on a map were found, even if they do not require a conceptual creation, but only pointing into places or territories (IM2, page 183). It must be bear in mind that working with images can be misleading because when asking to identify a concept through images, the meaning management is avoided and only a visual representation is used (EM2, page 202).

Conceptual contents are included in the activities under the headings of 'analyse, explain, define, compare, etc.' and imply the management of a great variety of concepts. Some of the concepts were directly related to the topic such as 'National-Catholicism' or 'totalitarian logic' and other was of general historic character such as 'ideology', 'international context' or 'political regime'.

Procedural contents appear in the activities under the instruction 'find information' or 'research' and require to locate information that is presented in documents included in the same textbook or that the student should look for on-line or in different archives and formats (audio, video, texts, etc.). An example of that can be found in the book ES2, page 331, in an activity that asks the student to write a report on the external policy of the Franco regime, using the texts and documents included in the textbook. In the EM1 textbook, in a section called 'Oral History' appears a procedural activity that implies a working technique based on selecting a topic, elaborating a questionnaire, interviewing selected persons, and finally, creating a report and elaborating conclusions.

Textbook IM1 provides activities with procedural contents that imply working with primary sources (sources $44-50$ included in pages 536-553) with the same format. When using these sources, students will have to compare and classify arguments and ideas of different authors to place themselves in a final position and write a text to justify it. In the IM2 textbook, pages 190-191, there is a procedural activity under the heading 'Discover your ability to...[In Italian]', in which through different exercises, students have to use primary sources, elaborate arguments to place themselves in the position of the main character in a historical period and to orally provide results.

The analysis of attitudinal contents has not included those activities that instruct students to 'value' as they do not mean establishing or working with assessing principles. In 
those cases, when used in the exercises' instructions, it means to consider or to assess the consequences of a historical fact. For example, in the textbook with code ES2, page 350, students are asked to 'value the importance of the technical means for Franco's regime'. It has been consequently considered that the instructions are ambiguous, that is, they do not ask the student to produce a judgment of value that will imply argumentation and the creation of a set of principles to value. What students are asked to do is to make a declaration based on the information provided by the course book.

In the EM2 textbook, page 221, there is an activity named 'link the present and the past'. Using historical memory, the student is asked to take a stance on some aspects. In this particular case, which is the only of its type found in the Spanish analysed textbooks, it seems to be an exercise of creation of principles to assess a controversial topic.

Two activities including attitudinal contents were identified in the IS1 textbook. One of them on page 142, in a section called MiniLab. The exercise asks the student to 'think historically' after having read some texts about fascist racism. Students are asked to mentally transport themselves to a 1938 classroom in which one of their fair-students is Jew and will suffer the prohibitions and persecution described in the text. Students are asked to imagine the possible reaction of the class and to describe them.

\section{Second category 'Didactic sequence'}

As stated before, introductory activities are not always present in the analysed textbooks. They only appeared in three out of the four Spanish textbooks included in the sample and did not appear in the Italian ones. It is logical to establish as general aims of introductory activities to explore students' previous conception and to familiarize them with the topic. However, in the analysed textbooks, introductory activities were looking for correct answers that correspond to specific data. An example of this appears in the EM1 textbook, Unit 14, 'From Dictatorship to Democracy'. The unit starts with a picture of Juan Carlos I King of Spain during his proclamation speech at the Spanish Parliament (page 266) and presents very specific questions such as: What's a constitution? Which one was the first Spanish Constitution? What is the current government form in Spain?. In this example, students asked to provide a precise answer, that is, a definition or some data for which no previous information has been given. Therefore, it has an evaluative character and/or is anticipating the main topic, but they not intended to be exploratory. The sole exception is the one found in the ES2 textbook. An image called Alegoría de Franco y la Cruzada by Arturo Reque Merubia (Kemer) (1948) is presented and the student is asked to guess what is trying to transmit. The image, that represents the dictator as a crusade, offers an open enough input and is full of different meanings to foster the exploration of ideas or conceptions of the collective imaginary during Franco's regime.

Within the development activities, we can find those referring to the body of the text and that include questions that are easily identified. It also has to be mentioned that the ES2 textbook supplies with a different type of activity that is integrated into the 
complementary documents. These documents are normally a complement to the text, an image, an article from a newspaper of that particular period, a paragraph belonging to a speech or an article from a legislative text, among others.

In the case of the closing activities there are two different types. On the one hand, those mean to create a sum up and to assess learning and, on the other hand, those intended to expand the acquired knowledge. Only two cases of final activities have appeared in the analysed textbooks, one in the Spanish ES1 textbook and the other in the Italian IS2, both of them devoted to the higher levels. Considering that, it can be affirmed that it is a model based on adding. First, the textbook offers the historical information that should be memorised and, secondly, the closing activities, will review, consolidate, or expand what has previously been learnt.

\section{Third category: 'Types of activities'}

Those activities considered mechanical, in the variety of modalities, require little intellectual exercise. Students only need to locate some data or piece of information helped by very clear indications. Answers are normally in the same page and in bold or italic characters. The textbook EM1, page 267, contains an example of this. It presents an activity in which the student has to define the terms 'dictatorship' and 'democracy', and, at the same page the following text can be found: 'a dictatorship is a regime based on autoritarism and repression, therefore, in people's rights and liberties limitation (freedom of speech, freedom to organise meetings)'.

Also, making lists or creating definitions or formulations is considered mechanical activities. In some activities, students are asked to observe and copy data in a chronological axis, or they are asked to enumerate a series of elements or characteristics of a historical period or referring to an institution. Some activities are defined as creating as descriptions, definitions, or explanations, even if what students have to do consist of copying elements that are included in the text provided. For example, in the textbook EM1, page 268 , students are asked to jot down in their notebooks three institutions from the totalitarian phase of Franco's dictatorship. In the same book, unit 12, page 273, students are asked to explain the features of the political opponents during the Franco's regime. In both cases, the answer is written down using the same words that appear in the question.

Other activities, that have been considered mechanical, are those asking students to 'relate elements included in a table'. In these activities, conceptual maps can be used. An example of this can be found in the ES1 textbook that asks students to 'relate the social and ideological support that Franco's regime had'. It should be noted that the required information appeared clearly defined in an enclosed conceptual map, in a section called 'social support'. Or when two columns with dates and names are provided and students are asked to establish a link between them. Thus, even if in the instructions of the activity the word relates appears, students' tasks only consists on identifying the right information following clear guidance. 
Some activities present direct questions. The textbook IS1, at the section 'Punti Fermi', pages 124-125, asks questions such as: What were the fascistísimas laws from 1925-1926? What was included in the plebiscitary electoral law? To answer these questions correctly, students do not really need to understand the text. Moreover, many answers where highlighted in the texts. The textbook IM1, page 161, presents activities with 'misleading instructions', for example, in the heading appears the term 'critical reflexion' but students are asked 'In which countries was the totalitarian ideology defended?'. Again, to correctly answer the question, students just need to identify it in the text provided in the very same page. The IM2 textbook includes two more examples of misleading instructions. The first one ask students to 'Understand the text' and the second one to 'Analyse the document'. Regardless the name use in the heading of the activities, both exercises will be correctly solved is some easy questions are simply and directly answered using the information included in the text provided.

Those activities referred to as comprehensive demand a more complex intellectual exercise. Students do not only have to copy the correct answer, they need a certain amount of intellectual elaboration and information management. Comprehensive activities are usually accompanied with text and images, and open questions that do not directly refer to the information provided by the textbook. On example of a comprehensive activity can be found in the EM1 textbook under the heading 'Read and Comment'. Students are presented a map with the US military bases established in Spanish land and have to answer this question: What was Spain's commitment and what did it received in exchange? The question implies a certain amount of reflexive thinking as a direct answer is not explicitly included in the textbook and, thus, students need to infer and justify it.

Another interesting comprehensive activity can be found in 'History in the classroom. Identifying historical consequences'. This activity uses as a starting point for some historic resources (a text, a table with percentages, two pictures, and three links to web pages). Students need to elaborate a table, in which they relate the causes and the political, economic, social and cultural consequences derived from economic autarchy during Franco's regime. However, as it requires the management of different information sources and the creation of a graphic expression of some data, it should be considered a comprehensive activity.

Another example of a comprehensive activity will be 'writing a historical report'. There is one case in which students are asked to create a historical report on the political isolation of Spain during Franco's dictatorship. To help them a historical text regarding the entrance of Spain in the United Nations Organization is provided. In the IS1 textbook, page 153, there are several comprehensive activities. In one of them, the heading asks students to 'develop arguments' regarding the Catholic position towards fascism. Another one called 'Writing History' asks students to write a short text and to provide a title for it. To do so, they have to use the historical documentation provided. In other activities, the instructions consist of 'formulating explicative hypothesis' regarding a 
historical event. An example of this will be the question: 'Why did the fascist regime imposed university lectures swearing loyalty towards it?. It is clear that all these activities require complex mental operations much more advanced than those required by the aforementioned mechanical activities.

In the case of quasi-investigative activities, several examples can be found in the analysed textbooks. One of them appears in the last part of the unit in the EM1 textbook. There, an activity called 'Work and research workshop', page 286, indicates students that they have to develop a piece of research following three steps. The first one is choosing a topic that is related to an event, a historical moment, or current daily aspects. The second one is the creation of a questionnaire and the development of an interview with a selected person that is familiarised with that particular event or who was a direct or indirect witness of that time. An in the third step; students have to present their work. The defined activity can be considered quasi-investigative. The activity can be described as 'class-work', because it understands research as a process that starts by choosing the topic, and continues by gathering information, selecting it, writing a report, and presenting it. Research aims, research problems, or hypothesis are not included; neither is data treatment of results presentation that will presumably be assessed by the teacher.

In the textbook ES2, there are four quasi-investigative activities, two of the on page 331 and the other two on page 349. The first of these activities present a series of historical texts and images that come with some questions that are to be used as a guide to analyse them. The second activity asks students to elaborate on a summarizing report that must be based on their previous work. To successfully complete both activities, students have to perform intellectual tasks that are very closed to those used in a research process (using several sources, analysing and managing data, elaborating final conclusions, etc.).

The IS1 textbook displays an activity called 'The right word', page 123. In that activity different electoral systems are defined through history and students have to develop a little research project about the current electoral system in Italy. The IS2 textbook presents an activity that gives students a list of arguments associated to some of the characteristics of fascism. Students have to choose one of them and to examine documents that stand for that particular opinion and documents that confront it. These two activities present a process that is very close to research, as students need to gather reliable information, manage it, and extract and communicate results.

The only participatory activity that can be found in the analysed sample is included in the IS1 textbook. It is called 'Identify and compare values and perspectives'. Students are asked to imagine that they are in an Italian school in 1940 and that they are listening to a fascist radio message. Guided by the teacher, students have to discuss the message and to take a stance. The activity is considered to be participative as, to successfully complete it, students have to build their argumentations mentally and also have to posture themselves actively. 
No activities of the category of research activities were found, as they do not fulfil the minimum requisites of a school research, as they do not include research problems or hypothesis. Also, when the research process is established, it normally is very reductionist as it is exclusively focused on information gathering and, in some cases, on results communication.

\section{Conclusions}

Analysed textbooks show that the number of mechanical activities is clearly higher when compared to other types of activities, both Italians and Spanish textbooks. However, the number of mechanical activities is slightly higher in the Spanish ones. To successfully complete mechanical activities, students only have to apply simple mental exercises. Here the pedagogical value of repetition is not questioned; however the overabundance of this type of exercises is proven and, consequently, the detriment of other types of more complex activities. These mechanical activities with a low complexity level do not require any kind of elaboration; students just have to copy fragments of texts (Sáiz, 2013).

Regarding the comparative analysis between medium and higher levels, results indicate that the percentage of mechanical activities is higher in medium level textbooks. This differentiation becomes more acute in the case of Spanish textbooks. These results are coherent with the fact that in both countries, the number of comprehensive activities in higher educational levels is more elevated.

When examining the type of content, conceptual ones are predominant. However, no distinction between the concepts' structural value is made, and, therefore, no links or hierarchy are established to mentally organise the concepts provided. Factual contents are also very numerous, especially chronological data, as well as descriptions based on the information provided, number of historical characters, dates, or historical events.

It must be highlighted that an important number of activities include concepts (general or specific from the Social Science fields), which are implicitly understood, as they are not explicitly worked. This leads to the conclusion that, as has been stated in previous works, the textbook discourse is addressed to a hypothetical standard student, who presumably has the necessary knowledge and skills to complete the activities (Martínez Bonafé, \& Rodríguez Rodríguez, 2010).

No activities including attitudinal contents requiring students the creation of assessment criteria were found. Students just had to position themselves by following the information included in the textbook. That implies losing the chance to debate on controversial topics and also the development of highly educational competences. According to Eisner $(2002,107)$ that can be considered null curriculum, what is not taught, what is kept silenced, that is, options not given to students, perspectives not taught and 
that students are not going to be able to use, concepts and skills that are not going to be included in the student's repertoire.

Cuesta (2009) affirmed that there is History with pedagogy in Primary Education and History without pedagogy in Secondary Education. Our research provides some pieces of evidence that point out a similar phenomenon in Secondary Education and Baccalaureate analysed textbooks. Compulsory Secondary Education textbooks present introductory and development activities, whereas Baccalaureate textbooks present closing activities, intended to review the learned contents. In this sense, as Cuesta already stated in 1998, Baccalaureate textbooks are compendiums of finished school knowledge that have been designed to be transmitted by the teacher. While Secondary Education activities are made to accompany the text reading, introducing pauses and helping to organise information; those intended for Baccalaureate use long texts that develop the studied topic and final activities to assess what has been learnt. In this way, compulsory textbooks activities present a didactic function that is not included in the activities of the Baccalaureate textbooks, where more importance is conceded to memorisation.

In line with previous research (Valls, 2008), analysed textbooks present a lack of didactic planning. Books reveal a great deal of historical rigour and describe events with concision and clarity; however, they lack the knowledge of the didactic content from an epistemological and pedagogical perspective. Furthermore, even if efforts to maintain the formal pedagogical rhetoric have been identified, they present no real didactic use. Examples of that are introductory activities that only require closed answers and that do not allow exploring students' ideas. Another example is working with concepts and offering just data and pieces of information. The case of some 'misleading activities' should be taken into account. The instructions of headings present a specific objective, but in practice, they are solved in a different manner.

In a conclusion, it can be stated that even if the topics worked within this study are potentially controversial, they are not always dealt with in a controversial manner. From a pragmatic perspective, the analysed textbooks offer the teacher a 'didactic recipe' to avoid feeling uncomfortable or insecure in the classroom when working with them (Díez Gutiérrez, 2011; Martínez Bonafé, 2008). In this way, the management of contents and activities is limiting the didactic opportunities bought by controversial topics, such as: debates, argumentations, and values working, among others. Analysed textbooks appear to take the conflictive character away from these controversial topics by dealing with them with a certain degree of neutrality.

As the main conclusion we can affirm that the analysed textbooks deprive contents of their controversial character when dealing with them neutrally and aseptically. This coldness means an ideological positioning and the teacher, who is a user of the textbook, may not always be aware of it. 


\section{References}

Aivelo, T., \& Uitto, A. (2019). Teachers' choice of content and consideration of controversial and sensitive issues in teaching of secondary school genetics. International Journal of Science Education, 41(18), 2716-2735.

Cohen, L., Manion, L, Morrison, K. (2013). Research methods in education. New York: Routledge.

Cotton, D. R. (2006). Teaching controversial environmental issues: Neutrality and balance in the reality of the classroom. Educational research, 48(2), 223-241.

Cuesta Fernández, R. (1998). Clío en las aulas. La enseñanza de la Historia en España entre reformas, ilusiones y rutinas. [Clio in the classrooms.Teaching History in Spain between Modifications, Illusions and Routines]. Madrid: Akal.

Cuesta Fernández, R. (2009). Sociogénesis de una disciplina escolar: la historia (versión electrónica). [Social generation of a school discipline]. Barcelona: Pomares-Corredor. http://www. historialudens.it/images/download/sociogenesisdeunadiscplinaescolar.pdf

Gutiérrez, E. J. D. (2011). Análisis de los textos escolares de historia. Estudio de caso sobre la posguerra civil española. [Analysis of textbooks through History. Case study regarding Spanish after Civil War]. Revista Historia de la Educación Latinoamericana, 16, 87-118.

Eisner, E. W. (2002). The educational imagination: On the design and evaluation of school programs. New Jersey, NY: Pearson Educational.

Hand, M., \& Levinson, R. (2012). Discussing controversial issues in the classroom. Educational Philosophy and Theory, 44(6), 614-629.

Hicks, D., \& Holden, C. (Eds.). (2007). Teaching the global dimension: Key principles and effective practice. London: Routledge.

Jerome, L., \& Elwick, A. (2020). Teaching about terrorism, extremism and radicalisation: some implications for controversial issues pedagogy. Oxford Review of Education, 46(2), 222-237.

Johnson, D. W., \& Johnson, R. T. (2009). Energizing learning: The instructional power of conflict. Educational Researcher, 38(1), 37-51.

Martínez Bonafé, J. (2008). Los libros de texto como práctica discursiva. [Textbooks as a discursive practice]. Revista de Sociología de la Educación-RASE, 1(1), 62-73.

Martínez, N., Valls, R., \& Pineda, F. (2009). El uso del libro de texto de Historia de España en Bachillerato: diez años de estudio, 1993-2003, y dos reformas (LGE-LOGSE). [The use of the History book in Spain; ten years of study, 1993-2003, and two modifications (LGE-LOGSE)]. Didáctica de las Ciencias Experimentales y Sociales, 23, 3-35.

Martínez Bonafé, J. \& Rodríguez Rodríguez J. (2010). El currículum y el libro de texto. Una dialéctica siempre abierta. [Syllabus and textbook. An always opened dialectic]. In J. Gimeno Sacristán (Ed.), Saberes e incertidumbres sobre el curriculum (pp. 246-268). Madrid: Morata.

McDonough, G. P. (2010). The problem of catholic school teachers deferring to the home on controversial religious issues. Catholic Education: A Journal of Inquiry and Practice, 13(3), 287-305. 
Oulton, C., Dillon, J., \& Grace, M. M. (2004). Reconceptualizing the teaching of controversial issues. International journal of Science Education, 26(4), 411-423.

Parker, W. C., \& Hess, D. (2001). Teaching with and for discussion. Teaching and Teacher Education, 17(3), 273-289.

Rodríguez-Pérez, R. A., Simón-García, M. M., \& Molina Puche, S. (2017). La Región de Murcia en los manuales escolares de educación secundaria. Una narrativa a la sombra de España y Europa. [Murcia Region in textbooks of secondary education. A narrative hidden by Spain and Europe]. Historia y Memoria de la Educación, 6, 241-277.

Sáiz Serrano, J. (2013). Alfabetización histórica y competencias básicas en libros de texto de historia y en aprendizajes de estudiantes. [Historical literacy and basic competences in History textbooks and in students' learning]. Didáctica de las Ciencias Experimentales y Sociales, 27, 43-66.

Schuitema, J., Radstake, H., van de Pol, J., \& Veugelers, W. (2018). Guiding classroom discussions for democratic citizenship education. Educational Studies, 44(4), 377-407.

Stradling, R., Baines, B., \& Noctor, M. (1984). Teaching controversial issues. London: Edward Arnold.

Travé, G., Pozuelos, F. J., Cañal, P., \& de las Heras, M. (2013). Experimentación de una guía de análisis de materiales y desarrollo de la enseñanza del medio natural y social. [Experimentation of amaterials analysis guide and teaching development of the natural and social environments]. Revista Investigación en la Escuela, 81, 5-20.

Valls, R. (2008). La enseñanza de la Historia y textos escolares. [Teaching History and school texts]. Buenos Aires: Zorzal,

Wellington, J. J. (Ed.). (1986). Controversial issues in the curriculum. London: Basil Blackwell. 


\title{
Prieštaringai vertinamos temos ir jų didaktinis pritaikymas: mokomujuc veiklų analizė Italijos bei Ispanijos vidurinio ugdymo istorijos vadovèliuose
}

\author{
Mario Ferreras-Listán ${ }^{1}$, José Antonio Pineda-Alfonso², Coral Ivy Hunt-Gómez ${ }^{3}$, Pablo Baisotti ${ }^{4}$ \\ Sevilijos universitetas, Eksperimentinių ir socialinių mokslų katedra, C/Pirotecnia, s/n, ES-41013, Sevilija, Ispanija, \\ mferreras@us.es \\ Sevilijos universitetas, Eksperimentinių ir socialinių mokslų katedra, C/Pirotecnia, s/n, ES-41013, Sevilija, Ispanija, \\ apineda@us.es \\ Sevilijos universitetas, Kalbos ir mokymo katedra, C/Pirotecnia, s/n, ES-41013, Sevilija, Ispanija, coralhuntg@us.es \\ Kosta Rikos universitetas, Kosta Rikos ir Lotynų Amerikos istorijos katedra, C/San Pedro de Montes de Oca, San \\ Chose, Kosta Rika, pablo.a.baisotti@hotmail.com
}

\section{Santrauka}

Šiame straipsnyje pateikiama panoraminè apžvalga, kurioje didaktiniu požiūriu nagrinèjami Franko diktatūros Ispanijoje (1939-1975) ir Musolinio fašizmo Italijoje (1922-1945) režimai, aprašomi vidurinio ugdymo istorijos vadovėliuose. Taikant aiškinamąją diskurso analizę drauge su kitais racionalistinès paradigmos instrumentais buvo išanalizuotos 278 mokomosios veiklos bei nustatytas jų didaktinis nuoseklumas, turinys ir tipologija.

Tyrimo rezultatai rodo, kad tiek italų, tiek ispanų vadovèliuose mechaninio mokymosi užduočių skaičius yra akivaizdžiai didesnis, palyginti su kitų rūšių veiklomis. Be to, nustatyta, kad vidurinio ugdymo lygmens vadovèliuose mechaninio mokymosi veiklų procentas yra didesnis. Nagrinėjant turinị pagal jo tipą, pastebimas konceptualus turinio dominavimas, nors pateikiama nemažai ir faktinès informacijos. Nerasta jokių veiklų, susijusių su mokinių pasaulèžiūrą formuojančiu turiniu, t. y. nesudaromos sąlygos, kad mokiniai galètų susikurti vertinimo kriterijus. Mokiniams tiesiog pateikiama vadovèlio informacija, nesuteikiant galimybès diskutuoti ginčytinomis temomis, todèl mokiniai praranda aukštesnes išsilavinimo kompetencijas.

Knygoms trūksta epistemiologinès ir pedagoginès perspektyvos. Ir nors nagrinèjamoje literatūroje akivaizdžiai pasisakoma už prieštaringai vertinamų temų nagrinejjimą, vis dèlto gauti rezultatai rodo, kad vengiama nepatogių temų, jos pateikiamos neutraliai. Be to, vadovèliai siūlo mokytojams „sterilų receptą“, kaip nagrinèti tokias temas.

Esminiai žodžiai: vadovèlis, pilietiškumo ugdymas, istorijos ir kultūros mokymas, vidurinis ugdymas.

Gauta 20200520 / Received 20052020

Priimta 20200909 / Accepted 09092020 